\title{
OPEN Genotoxic and oxidative effect of duloxetine on mouse brain and liver tissues
}

\author{
Isela Álvarez-González ${ }^{1}$, Scarlett Camacho-Cantera ${ }^{1}$, Patricia Gómez-González ${ }^{1}$, \\ Michael J. Rendón Barrón ${ }^{1}$, José A. Morales-González ${ }^{2}$, Eduardo O. Madrigal-Santillán ${ }^{2}$, \\ Rogelio Paniagua-Pérez ${ }^{3}$ \& Eduardo Madrigal-Bujaidar ${ }^{1 \bowtie}$
}

We evaluated the duloxetine DNA damaging capacity utilizing the comet assay applied to mouse brain and liver cells, as well as its DNA, lipid, protein, and nitric oxide oxidative potential in the same cells. A kinetic time/dose strategy showed the effect of 2,20 , and $200 \mathrm{mg} / \mathrm{kg}$ of the drug administered intraperitoneally once in comparison with a control and a methyl methanesulfonate group. Each parameter was evaluated at 3,9, 15, and $21 \mathrm{~h}$ postadministration in five mice per group, except for the DNA oxidation that was examined only at $9 \mathrm{~h}$ postadministration. Results showed a significant DNA damage mainly at $9 \mathrm{~h}$ postexposure in both organs. In the brain, with 20 and $200 \mathrm{mg} / \mathrm{kg}$ we found 50 and $80 \%$ increase over the control group $(p \leq 0.05)$, in the liver, the increase of 2,20 , and $200 \mathrm{mg} / \mathrm{kg}$ of duloxetine was 50,80 , and $135 \%$ in comparison with the control level $(p \leq 0.05)$. DNA, lipid, protein and nitric oxide oxidation increase was also observed in both organs. Our data established the DNA damaging capacity of duloxetine even with a dose from the therapeutic range $(2 \mathrm{mg} / \mathrm{kg})$, and suggest that this effect can be related with its oxidative potential.

A major depressive disorder is one of the most common and debilitating mental problem worldwide. The disease is characterized by impairments in cognition, emotional regulation, memory, and motoric function, motivation, and neurovegetative symptoms; in addition to these primary effects, the disorder can also cause several secondary disabilities which may represent a high economic burden for the involved family and the government ${ }^{1}$. Pharmacotherapy plays an important role in the disease treatment although there is no consensus about which drug can be the most useful as a first option, considering the possibility of its long-term use and the patient's clinical variability ${ }^{2}$.

A study about the relative efficacy, acceptability, and tolerability of antidepressants concluded that one of the recommended drugs for depression is duloxetine ${ }^{3}$; besides, the medicament is also used against other mental problems, as well as inflammation and pain. Duloxetine is a serotonin and norepinephrine uptake inhibitor, that has a low affinity for most 5-HT subtypes, and muscarinic, histamine H1, alpha1-adrenergic, alpha2-adrenergic, and dopamine $\mathrm{D} 2$ receptors ${ }^{4}$.

Toxicological studies of the drug have shown similar moderate collateral effects as observed in most antidepressants, mainly including the gastrointestinal and nervous systems, and few aggressive damage in specific organs, such as in the liver ${ }^{5}$.

Concerning the genotoxic field and related areas, few studies have been published in in vitro and in vivo assays. Di Poi et al. ${ }^{6}$ detected embryotoxicity induced by the examined medication in the oyster Crassostrea gigas, Lassen et al. ${ }^{7}$ observed an increase in the rate of outcomes with major congenital malformations during the first trimester of pregnancy in women under treatment; from 668 infants the authors found 16 with malformations and estimated relative risk of 0.80 . Concerning genotoxic and carcinogenic studies, Brambilla et al. ${ }^{8}$, summarized the effect of the antidepressant in various in vitro and in vivo assays with negative results although the tested doses were not provided; however, the authors reported a positive carcinogenic effect in the rat liver, Respect to its in vivo genotoxic potential, a report published by Madrigal-Bujaidar et al. ${ }^{9}$ evaluated the capacity of the drug to induce micronuclei in mouse blood cells, and found a moderate effect of the antidepressant in both, an acute and a subchronic assay; besides, by examining the number of sister chromatid exchanges in mouse bone

${ }^{1}$ Laboratorio de Genética, Instituto Politécnico Nacional, Escuela Nacional de Ciencias Biológicas, Av. Wilfrido Massieu s/n. Zacatenco, Ciudad de México 07738, México. ${ }^{2}$ Laboratorio de Medicina de La Conservación, Instituto Politécnico Nacional, Escuela Superior de Medicina, Plan de San Luis Y Díaz Mirón S/N, Casco de Santo Tomás, Ciudad de México 11340, México. ${ }^{3}$ Servicio de Bioquímica, Instituto Nacional de Rehabilitación, Av. México-Xochimilco 289, Ciudad de México 14389, México. ${ }^{\circledR}$ email: edumadrigal.bujaidar@gmail.com 
marrow, the same authors again demonstrated a moderate but significant increase of this parameter ${ }^{10}$. Respect to the application of the comet assay, a previous report revealed no damage by the antidepressant in the mouse brain and blood cells ${ }^{11}$. However, considering that observations were made $24 \mathrm{~h}$ after the drug exposure, we feel pertinent to re-apply the same assay using a different strategy; therefore, a first objective of the present report was to examine the drug's capacity to affect the DNA using the comet assay in the mouse brain and hepatic cells, but using a kinetic-time design in an attempt to detect the drug's effect at four different time-points after the mouse exposure. Besides, in light of the previously reported chromosomal damage by duloxetine, and because of the presence of potentially oxidant chemical groups in the molecule, such as the naphthyl ring, and the potential oxidative effect during its metabolism due to the formation of epoxides, a second objective of the present study was to also perform a kinetic-time study on the oxidative capacity of the medication regarding DNA, lipids, proteins, and nitric oxide.

\section{Materials and methods}

Chemicals and animals. Duloxetine hydrochloride was obtained as the usually prescribed antidepressant (Cymbalta, Eli Lilly \& Co., Mexico), CAS number 136434-34-9, molecular formula $\mathrm{C}_{18} \mathrm{H}_{19} \mathrm{NOS}^{12}$. The following substances were obtained from Sigma Chemicals (St Louis Mo. USA): triton X-100, dimethyl sulfoxide (DMSO), methyl methanesulfonate (MMS), sodium chloride, tris, normal melting point agarose (NMPA), low melting point agarose (LMPA), calcium and magnesium free phosphate-buffered saline (PBS), ethydium bromide (EB), trypan blue solution, N-lauroyl-sarcosine (sodium salt), HEPES, bovine serum albumin (BSA), Bradford reagent, thiobarbituric acid (TBA), trichloroacetic acid (TCA), 2,4-dinitrophenylhydrazine (DNPH), guanidine, sulfanilamide, N-1-(naftil) etilendiamine dichloride, and the enzyme formamidopyrimidine-DNA glycosylase (FPG). Besides, potassium hydroxide, potassium chloride, sodium hydroxide, EDTA, ethanol, ethyl acetate, formic acid, methanol, and hydrochloric acid $(\mathrm{HCl})$ were purchased from Baker (Phillipsburg NJ, USA).

For the assay, we used 100 male mice (ICR) with a mean weight of $23 \mathrm{~g}$ (Harlan Laboratory, Mexico City). Five mice per cage and 20 per experimental group were placed in polycarbonate cages at $24{ }^{\circ} \mathrm{C}, 12 \mathrm{~h}$ dark-light cycles, 50\% relative humidity, and with free access to water and food (Rodent Chow 5001, Purina). The experiment was approved by the Bioethics Committee of the Hidalgo State Autonomous University (Mexico) and was started after a week of animal stabilization in the Genetics animal facility, according to the previously indicated conditions. Besides, we confirm that all used methods in the present research were performed according to the recommended international guidelines and regulations, as reported in ARRIVE guidelines, published in https:// arriveguidelines.org ${ }^{13}$.

For the standard comet assay we had the following groups of animals with twenty mice each: a control group intragastrically administered purified water, a positive control group intraperitoneally administered $150 \mathrm{mg} / \mathrm{kg}$ of methyl methanesulfonate, and three groups intragastrically administered duloxetine in the doses of 2, 20, and $200 \mathrm{mg} / \mathrm{kg}$. The highest dose corresponded to $70 \%$ of the DL $\mathrm{L}_{50}$ previously obtained in our laboratory $(282 \mathrm{mg} / \mathrm{kg}$ by the intragastric route), and the low dose corresponded to the high dose range recommended for daily therapeutic use in humans. The same mentioned chemicals and doses of duloxetine were used in the other oxidative tests applied in the present work. Observations for each genotoxic and oxidative parameters were made at 3, 9, 15 , and $21 \mathrm{~h}$ post-administration, except for the comet assay plus FPG that was made at $9 \mathrm{~h}$, only.

Comet assay: Standard technique. Each mouse was dissected to obtain the brain and the liver. Concerning the brain, about $4 \mathrm{~mm}$ of the tissue were deposited in $250 \mathrm{ml}$ of PBS, repeatedly hit with a syringe plunger to finally place $40 \mathrm{ml}$ of the cell suspension on ice, while the liver was disaggregated with scissors, the lumps eliminated and the cells also placed in cold PBS. The comet assay procedure was based on published guidelines on the method ${ }^{14}$. We used about $10000 \mathrm{cells} / \mathrm{ml}$ in each tested sample with the viability of more than $80 \%$ according to the trypan blue staining method.

We used fully frosted slides coated with three layers of agarose: initially, $120 \mu \mathrm{l}$ of $1 \%$ NMPA made in PBS were placed in a coverslip, left to solidify for $4 \mathrm{~min}$ at $4{ }^{\circ} \mathrm{C}$ and placed in a slide, then, on top of such layer of agar we added a second layer constituted by $75 \mu \mathrm{l}$ of $1 \%$ LMPA made in PBS, plus $20 \mu \mathrm{l}$ of the cell suspension (brain or liver), and finally, the last layer constituted by $75 \mu \mathrm{l}$ of $1 \%$ LMPA was added. Three slides per treatment/ exposure time were made, protected from light, and placed for $24 \mathrm{~h}$ in the lysis solution constituted by $\mathrm{NaCl}$ $2.5 \mathrm{M}$, EDTA $100 \mathrm{mM}$, tris $10 \mathrm{mM}$, sodium sarcosinate 1\%, plus triton X-100 1\% and DMSO 10\%, pH 10. Slides were then placed in an electrophoresis chamber containing $\mathrm{NaOH} 300 \mathrm{mM}$, plus EDTA $1 \mathrm{mM}$ at $\mathrm{pH}>13$ for $20 \mathrm{~min}$ before carrying out the electrophoresis at $25 \mathrm{v}, 250 \mathrm{~mA}$, and $\mathrm{pH}>13$ for $20 \mathrm{~min}$. After this step, cells were washed with tris $(0.4 \mathrm{M}, \mathrm{pH} 7.5)$ for $5 \mathrm{~min}$, and each slide was stained with $\mathrm{EB}(25 \mu \mathrm{g} / \mathrm{ml})$. The comet tail length/ nucleus diameter index was analyzed in 100 nucleoids per individual/treatment/ time utilizing an epifluorescent microscope (Axioscope, Carl Zeiss) equipped with emission and excitation filters of 488 and $565 \mathrm{~nm}$, respectively. The microscope was adapted to an image analyzer Image-Pro Plus (Media Cybernetics).

The statistical analysis of the obtained results was made with the ANOVA test followed by the Student-Newman-Keuls test, using the Program SigmaStat version 3.5.

Comet assay: With the inclusion of the FPG enzyme. To evaluate the capacity of duloxetine to oxidize the DNA molecule we applied the comet assay plus the addition of the FPG enzyme. Parallel slides initially prepared for the previous assay were used. However, in this case, after cells passed through the lysis solution, they were washed three times, 5 min each, with the enzyme buffer constituted by HEPES $40 \mathrm{mM}, \mathrm{KCl} 0.1 \mathrm{M}$, EDTA $0.5 \mathrm{mM}$, and albumin bovine serum $0.2 \mathrm{mg} / \mathrm{ml}$, at $\mathrm{pH}$ 8.0. The obtained enzyme had $10 \mu \mathrm{g}$ of FPG. These were diluted in $2 \mathrm{ml}$ of the buffer solution to produce a stock solution of $5 \mu \mathrm{g} / \mathrm{ml}$, then, $10 \mu \mathrm{l}$ of such solution were added to $40 \mathrm{ml}$ of buffer. In this form we obtained an FPG final concentration of $1 \mu \mathrm{g} / \mathrm{ml}$. We added the 
$50 \mu \mathrm{l}$ the final solution to each slide that was covered it with a cover slide and placed in a humid chamber for $45 \mathrm{~min}$ at $37^{\circ} \mathrm{C}$. Slides were then placed at $4{ }^{\circ} \mathrm{C}$ for $5 \mathrm{~min}$, the coverslips were removed, and the DNA denatured with a solution of $\mathrm{NaOH} 300 \mathrm{mM}$, plus EDTA $1 \mathrm{mM}$, at pH 13 for $40 \mathrm{~min}$; finally, the electrophoresis was carried out at $25 \mathrm{v}, 300 \mathrm{~mA}$, and $\mathrm{pH}>13$ for $30 \mathrm{~min}^{15}$. After this step, the procedure, scoring, and statistical analysis were made as described above for the standard technique.

Total protein determination. For this determination, we followed the method described by Bradford ${ }^{16}$. Initially, the tissues were homogenized in PBS (1:10), then, $100 \mu \mathrm{l}$ of homogenate from each tissue was centrifuged at $9000 \mathrm{rpm}$ for $10 \mathrm{~min}$, and $10 \mu \mathrm{l}$ of the obtained supernatant was mixed with $90 \mu \mathrm{l}$ of deionized water and $2.5 \mathrm{ml}$ of Bradford's reagent, after which the mix was agitated for $5 \mathrm{~min}$. Samples were spectrophotometrically read at $595 \mathrm{~nm}$ against a blank made with $100 \mathrm{ul}$ of deionized water plus $2.5 \mathrm{ml}$ of Bradford's reagent. The results were interpolated in a bovine serum albumin standard curve $(0.1$ to $1.0 \mathrm{mg} / \mathrm{ml})$ and expressed as $\mathrm{mg}$ protein/g tissue.

Determination of lipid peroxidation. For this determination, we used the method of Buege and Aust ${ }^{17}$, that register the concentration of malondialdehyde (MDA) as the affected parameter. Briefly, the organs were homogenized 1:10 in PBS, and then, to $500 \mu \mathrm{l}$ of homogenate from each tissue, we added $2 \mathrm{ml}$ of the reaction mixture (TCA-TBA- $\mathrm{HCl}$ ) at $15 \% \mathrm{w} / \mathrm{v}, 0.375 \mathrm{w} / \mathrm{v}$, and $0.25 \mathrm{~N}$, respectively. The mixture was boiled for $15 \mathrm{~min}$, cooled in an ice bath for $10 \mathrm{~min}$, and centrifuged at $4000 \mathrm{rpm}$ for $10 \mathrm{~min}$. Then, the supernatant was spectrophotometrically read at $532 \mathrm{~nm}$ against a reference blank. The concentration of MDA was calculated by using an extinction coefficient of $1.56 \times 10^{5} \mathrm{M}^{-1} \mathrm{~cm}^{-1}$. The results were expressed as nmol MDA/mg protein.

Determination of oxidized proteins. This measurement was made through the quantification of the reactive carbonyl content according to the method of Levine et al. ${ }^{18}$. Each tissue was homogenized in PBS (1:10) followed by the addition of $500 \mu \mathrm{l}$ of $\mathrm{DNPH}(10 \mathrm{mM}$ in $\mathrm{HCl} 2 \mathrm{mM})$ to $200 \mu \mathrm{l}$ of the tissue homogenate. The mixture was placed at room temperature in the dark for $1 \mathrm{~h}$, and the generated hydrazones were precipitated with $500 \mu \mathrm{l}$ of $20 \%$ TCA. Each sample was centrifuged three times at $9000 \mathrm{rpm}$ for $10 \mathrm{~min}$ and each time, the suspension was washed with $1 \mathrm{ml}$ of ethyl acetate-ethanol 1:1. The pellet was re-suspended in $1 \mathrm{ml}$ of hydrochlorate guanidine $6 \mathrm{M}$, incubated at $37^{\circ} \mathrm{C}$ for $15 \mathrm{~min}$, and centrifuged at $9000 \mathrm{rpm}$ for $10 \mathrm{~min}$. For each sample, we concurrently followed the same procedure with a blank incubated with $500 \mu \mathrm{l}$ of $\mathrm{HCl} 2 \mathrm{M}$ without DNPH. The carbonyl content was spectrophotometrically registered in a range from 350 to $375 \mathrm{~nm}$, and its concentration was calculated by using $22,000 \mathrm{M}^{-1} \mathrm{~cm}^{-1}$ as the coefficient of molar absorbance. Results were expressed as nmol of $\mathrm{CO} \bullet / \mathrm{mg}$ protein.

Nitric oxide determination. We prepared a homogenate (1:4) from each tissue by adding cold PBS. Then, $600 \mu \mathrm{l}$ of the homogenate were centrifuged for $20 \mathrm{~min}$ at $4000 \mathrm{rpm}$ and the supernatant was treated with the Griess reaction to determine the concentration of nitrites ${ }^{19}$. For this purpose, $300 \mu \mathrm{l}$ of the Griess reactive plus $600 \mu \mathrm{l}$ of distilled water were added to $100 \mu \mathrm{l}$ of the obtained supernatant. The mixture was then measured at $540 \mathrm{~nm}$. As a standard, we used $\mathrm{NaNO}_{2} 0.1 \mathrm{Mm}$ in a range from $0.9 \mu \mathrm{mol}$ to $10 \mu \mathrm{mol}$. The results were expressed as $\mu \mathrm{mol}$ of nitrite/g of tissue.

\section{Results}

Comet assay: Standard and with the FPG enzyme. The results of the comet tail length/nucleus diameter index obtained in the brain with the standard method are shown in Fig. 1. It was observed as a low and constant value along with the assay in the control group, a result that contrasts with the elevated DNA damage manifested by the exposure to MMS during the different examined time points. However, the effect was higher at $9 \mathrm{~h}$ post-exposure (four times over the control value) followed by a certain decrease, a behavior usually observed when the cells are exposed to a single administration. Concerning duloxetine, it was interesting to note a statistically significant damage increase also at $9 \mathrm{~h}$ post-exposure, indicating that this time was optimal to detect the DNA effect induced by the antidepressant. In the doses 20 and $200 \mathrm{mg} / \mathrm{kg}$ we found 50 , and $80 \%$ increase over the control group, respectively, although the lower dose showed no genotoxic effect.

As regards to the liver cells, the response observed in the negative and the positive control animals was similar to the described above (Fig. 2). Concerning duloxetine, the damage was more evident than in cerebral cells. The high dose induced a significant effect since the first observed data point, and the three tested doses were statistically significant from the control value at 9 and $15 \mathrm{~h}$ post-treatment. However, the highest damage was found after $9 \mathrm{~h}$ of exposure, similarly to those observed in brain cells. At this time, the increase of 2, 20, and $200 \mathrm{mg} /$ $\mathrm{kg}$ of the drug was $50 \%, 80 \%$, and $135 \%$ respectively, in comparison with the control level.

To examine the influence of the DNA oxidation in our results we analyzed the effect of duloxetine in preparations added with FPG at $9 \mathrm{~h}$ after the drug' exposure. Figure $3 \mathrm{~A}$ shows the comparison of results obtained without and with the addition of the enzyme in brain cells, while Fig. 3B shows data obtained in hepatic cells. In the case of brain cells, we found that FPG provoked $59 \%$ comet increase when $20 \mathrm{mg} / \mathrm{kg}$ of duloxetine was administered, in comparison with the level determined without the enzyme; also, we observed a 77\% DNA damage increase with the addition of $200 \mathrm{mg} / \mathrm{kg}$ duloxetine respect to the level determined with no enzyme added. Concerning hepatic cells, the effect was slightly stronger, $76 \%$ and $99 \%$ with 20 and $200 \mathrm{mg} / \mathrm{kg}$ over the control level, respectively. These results established the DNA oxidation effect of the antidepressant with the two high doses tested. 


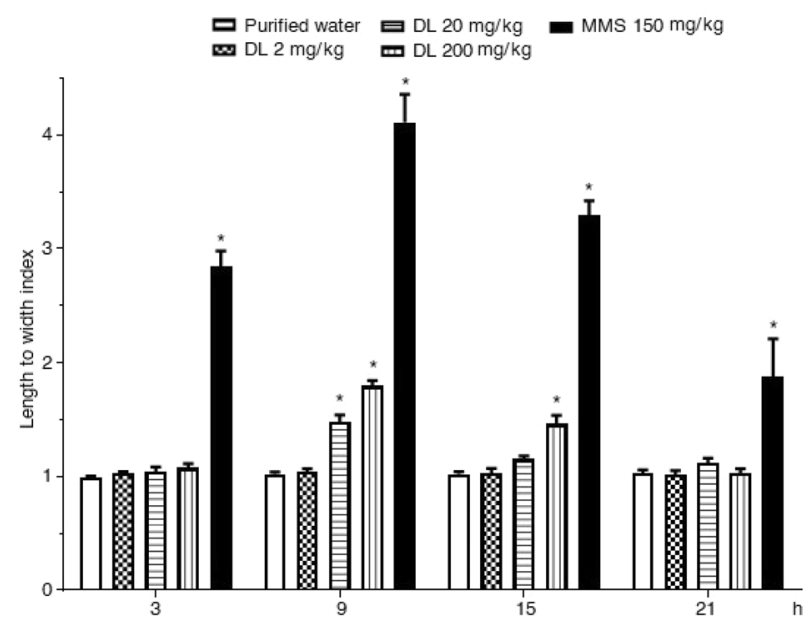

Figure 1. Mouse brain cells exposed to duloxetine (DL) and methyl metanesulfonate (MMS). Evaluation with the comet assay along $21 \mathrm{~h}$ after a single administration. Each bar represents the mean \pm SEM of 5 mice per group. 100 nucleoids per animal. ${ }^{\star}$ Statistically significant difference with respect to control value. ANOVA and post hoc Student-Newman-Keuls tests $(p \leq 0.05)$.

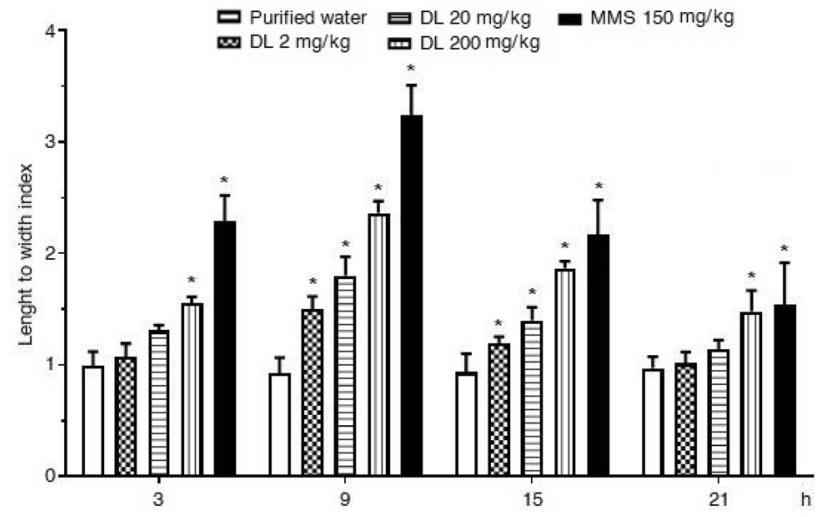

Figure 2. Mouse hepatic cells exposed to duloxetine (DL) and methyl metanesulfonate (MMS). Evaluation with the comet assay along $21 \mathrm{~h}$ after a single administration. Each bar represents the mean \pm SEM of 5 mice per group. 100 nucleoids per animal. ${ }^{\star}$ Statistically significant difference with respect to control value. ANOVA and post hoc Student-Newman-Keuls tests $(p \leq 0.05)$.

Oxidative effect: Lipids, proteins, and nitric oxide. Figure 4 shows the effect of duloxetine on brain lipoperoxidation. It was observed as a low and constant malondialdehyde level in the control group along with the assay, and a high malondialdehyde increase content induced by MMS, which showed a decreased curve with the assay. Concerning duloxetine, we determined a significant malondialdehyde increase at $3 \mathrm{~h}$ post-exposure with the two high doses; however, the more significant damage was expressed after $9 \mathrm{~h}$ of exposure, where even the low dose $(2 \mathrm{mg} / \mathrm{kg})$ produced a $75 \%$ damage increase in comparison with the control group. Even though the kinetic curve decreased after such schedule, duloxetine was also a lipid oxidative agent at $15 \mathrm{~h}$ and $21 \mathrm{~h}$ with the two high doses tested.

A similar result was obtained concerning hepatic cells; however, in this case, the response of the drug was somewhat stronger (Fig. 5). While in the control and the MMS treated group, the malondialdehyde level showed similar behavior to those described in brain cells, the three doses of the antidepressant increased the lipid biomarker during the examined schedule except at $21 \mathrm{~h}$. With respect to the control level, at $9 \mathrm{~h}$ post-exposure, the increase was 43,102 , and $168 \%$ with 2,20 , and $200 \mathrm{mg} / \mathrm{kg}$, respectively.

Results regarding oxidized proteins are presented in Figs. 6 and 7 respect to brain and hepatic cells, respectively. In the first figure, we observed a significant increase of oxidized carbonyls at $3 \mathrm{~h}$ and $9 \mathrm{~h}$ post-exposure, mainly induced with the two high doses tested, such increase was found in the range of the results observed with the selected positive mutagen. Results in liver cells (Fig. 7) showed that the three tested doses of duloxetine were statistically significant at $3 \mathrm{~h}$ and $9 \mathrm{~h}$ against the control level, a difference that was also present at $15 \mathrm{~h}$ with the two high doses, and at $21 \mathrm{~h}$ with the highest dose. At $9 \mathrm{~h}$ the elevation with respect to the untreated cells corresponded to $24 \%, 34 \%$ and $55 \%$ with 2,20 and $200 \mathrm{mg} / \mathrm{kg}$ of duloxetine, respectively. At the same time, in the brain, the increase corresponded to $28 \%, 114 \%$ and $148 \%$ with 2,20 , and $200 \mathrm{mg} / \mathrm{kg}$, respectively. 


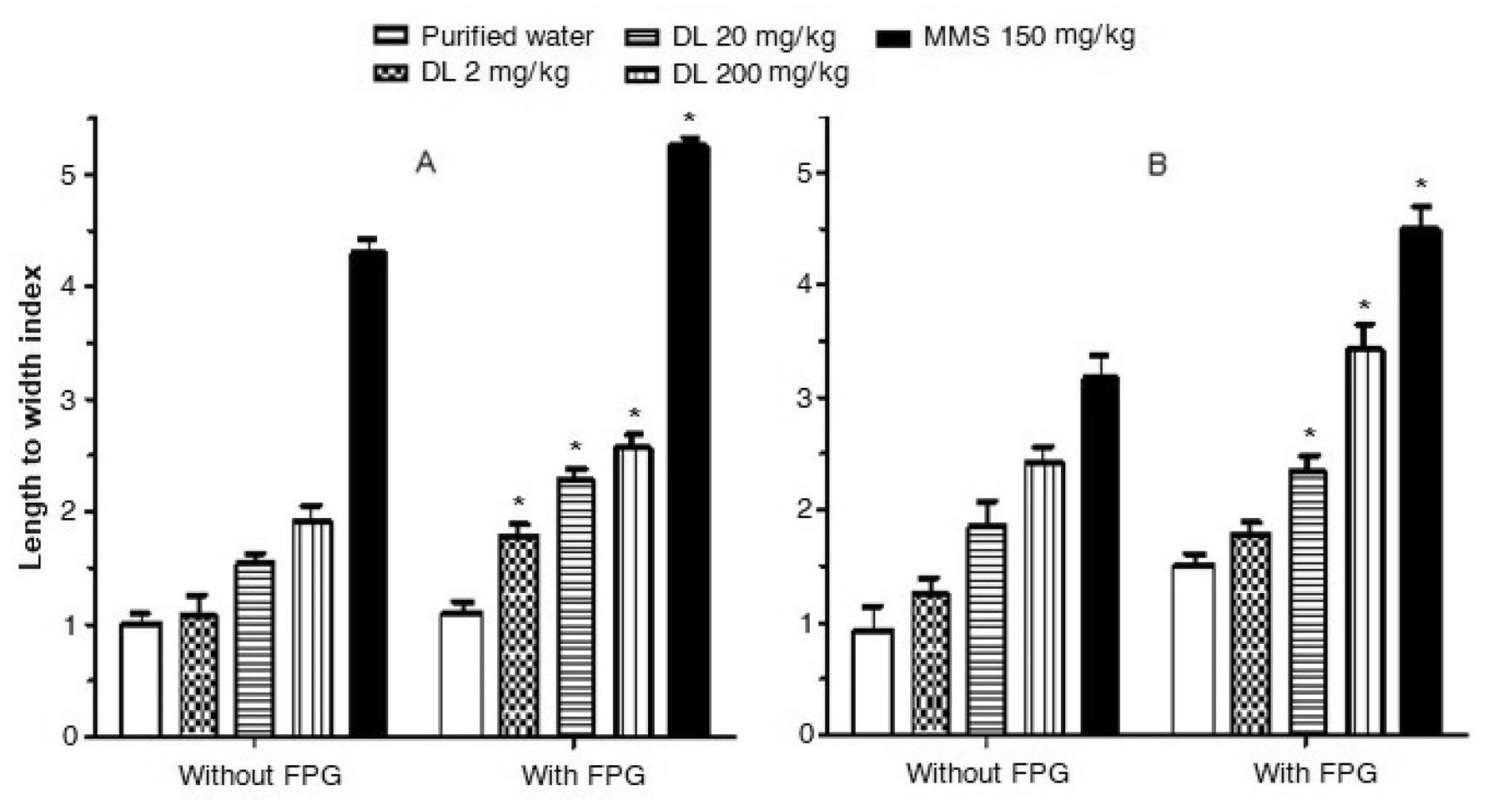

Figure 3. Mouse brain (A) and liver cells (B) treated with duloxetine (DL) and methyl metanesulfonate (MMS). Comet assay added or not with the enzyme formamido pyrimidine-DNA glycosilase (FPG). Results correspond to the effect of a single administration of each compounds evaluated at $9 \mathrm{~h}$ post-administration. Each bar correspons to the mean \pm SEM obtained in 100 nucleoids per mouse, 5 mice per group. ${ }^{\star}$ Statistically significant difference with respect to the value without FPG. ANOVA and post hoc Student-Newman-Keuls tests $(p \leq 0.05)$.

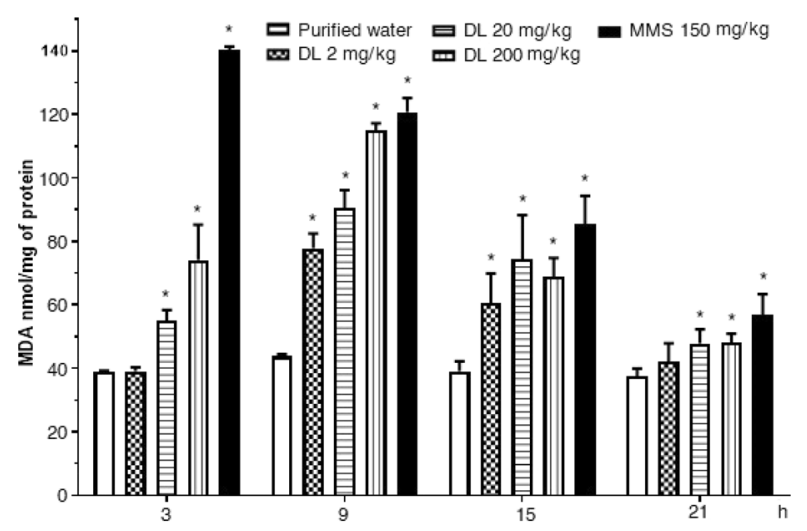

Figure 4. Effect of duloxetine (DL) and methyl metanesulfonate (MMS) on the content of malondialdehyde (MDA) in mouse brain cells. Each bar corresponds to the mean \pm SEM obtained in 5 independent determinations made in triplicate. ${ }^{\star}$ Statistically significant difference with respect to control value. ANOVA and post hoc Student-Newman-Keuls tests $(p \leq 0.05)$.

Finally, the results on oxidation products of nitrogen oxide are shown in Fig. 8 for the brain and in Fig. 9 for the liver. In brain cells, we observed no effect of duloxetine along with the whole assay, contrary to a moderate elevation of this parameter in hepatic cells. In comparison with the control value, the damage that was statistically significant at 3 and $9 \mathrm{~h}$ after the antidepressant exposure. Concerning untreated mice, at $9 \mathrm{~h}$ post-exposure, the increase with 2, 20 and $200 \mathrm{mg} / \mathrm{kg}$ of duloxetine was $9 \%, 26 \%$, and $17 \%$ respectively.

\section{Discussion}

There are approximately 350 million people worldwide with depression, a fact that supports the relevance of pharmacotherapy as a key role in the treatment of the disease ${ }^{20}$. Moreover, it is known that antidepressants may be used in short or long-term treatments, and, therefore, it is understandable the need for the safe use of such medications. In this context, it has been recognized that variations in the DNA molecule and its function, along with the effect of environmental influences are key factors that explain the development of numerous disorders such as single-gene diseases, chromosomal imbalances, epigenetics, cancer, and complex disorders ${ }^{21}$. In parallel 


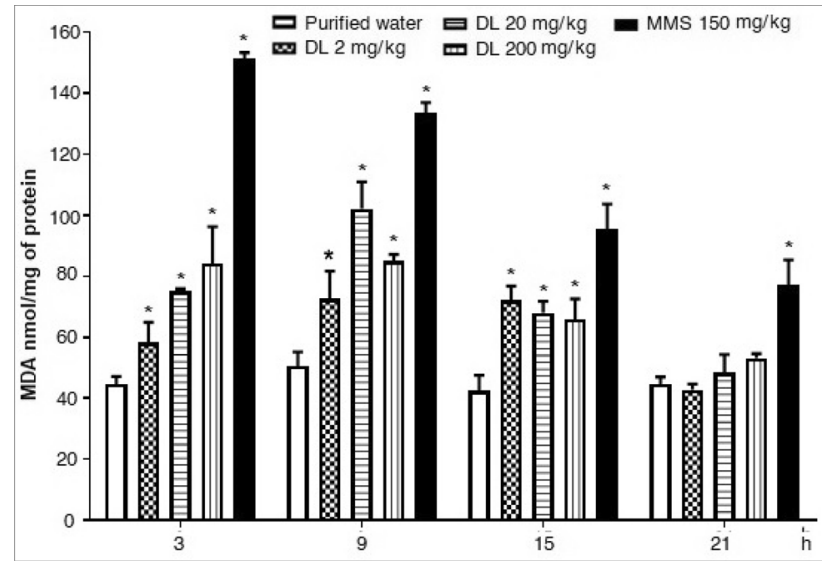

Figure 5. Effect of duloxetine (DL) and methyl metanesulfonate (MMS) on the content of malondialdehyde (MDA) in mouse hepatic cells. Each bar corresponds to the mean \pm SEM obtained in 5 independent determinations made in triplicate. ${ }^{*}$ Statistically significant difference with respect to control value. ANOVA and post hoc Student-Newman-Keuls tests $(p \leq 0.05)$.

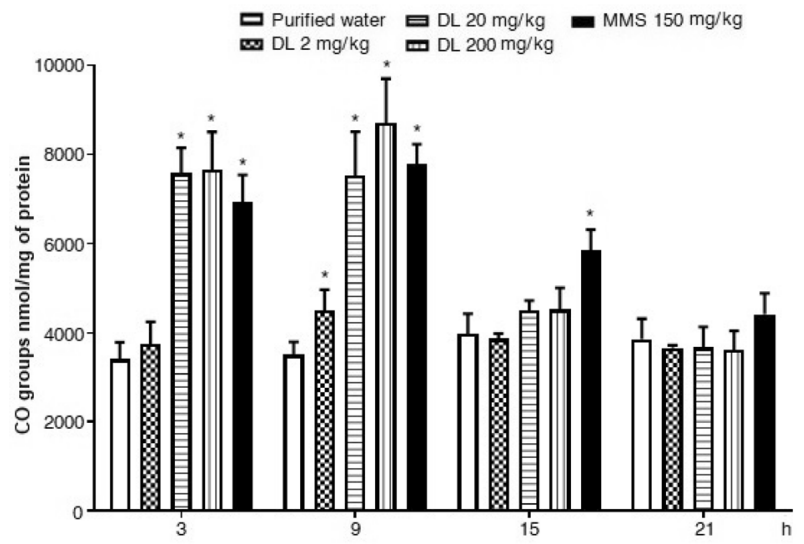

Figure 6. Effect of duloxetine (DL) and methyl metanesulfonate (MMS) on the content of oxidized carbonil groups $(\mathrm{CO} \bullet)$ in mouse brain cells. Each bar corresponds to the mean \pm SEM obtained in 5 independent determinations made in triplicate. ${ }^{\star}$ Statistically significant difference with respect to control value. ANOVA and post hoc Student-Newman-Keuls tests $(p \leq 0.05)$.

with this knowledge, several assays to detect damage in DNA and chromosomes have been developed and widely applied, among several purposes, to examine the genotoxic effect of medications, including antidepressants, in in vitro and in vivo assays. One of these genotoxic methods is the single cell gel electrophoresis assay, usually known as comet assay, which is a versatile tool that has good sensitivity, adaptability, and reliability, and may be applied to most cells to measure DNA strand breaks, incomplete excision repair events, alkaline labile sites, and cross-linking events 22 .

In the present report, we initially applied the alkaline version of the comet assay to mouse liver cells administered duloxetine and found a high level of damaged DNA with the high dose at all examined times, moreover, more interesting was that the three tested doses were genotoxic in liver at 9 and $15 \mathrm{~h}$ of the assay. In the brain, however, the effect of the high dose was observed only at 9 and $15 \mathrm{~h}$ although with lower potency than in hepatic cells, and the intermediate dose $(20 \mathrm{mg} / \mathrm{kg})$ had a genotoxic effect only at $9 \mathrm{~h}$ post-administration. The stronger effect of duloxetine in liver cells was probably related to the chemical biotransformation process in such organ, where the drug is subjected to oxidation, methylation, and conjugation pathways, to the action of enzymes such as CYP2D6 and CYP1A1, and the formation of metabolites which include the glucuronide conjugate of 4-hydroxy duloxetine, and the sulfate conjugate of 5-hydroxy, 6-methoxy duloxetine ${ }^{23}$.

Our data suggest that the optimal time for duloxetine to induce DNA damage was at $9 \mathrm{~h}$ post-administration, a result which is congruent with the reported pharmacokinetic behavior of the drug, which has shown a high mean plasma concentration from 6 to $12 \mathrm{~h}$ and a $\mathrm{t}_{1 / 2}$ of $11.1 \mathrm{~h}^{23,24}$. Besides, the DNA damage time-course strategy applied to potential genotoxicants has been useful to examine the detoxification and DNA repair processes whether in cultivated cells or in in vivo assays. In our case, the break removal process started after $9 \mathrm{~h}$ posttreatment and its stronger effect reached the control level at $21 \mathrm{~h}$ with all tested doses in brain cells, and also 


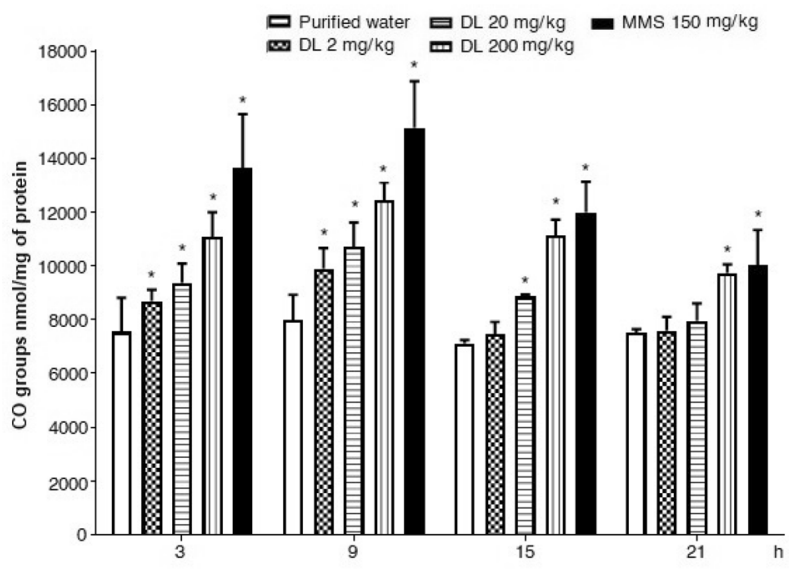

Figure 7. Effect of duloxetine (DL) and methyl metanesulfonate (MMS) on the content of oxidized carbonil groups (CO•) in mouse hepatic cells. Each bar corresponds to the mean \pm SEM obtained in 5 independent determinations made in triplicate. ${ }^{\star}$ Statistically significant difference with respect to control value. ANOVA and post hoc Student-Newman-Keuls tests $(p \leq 0.05)$.

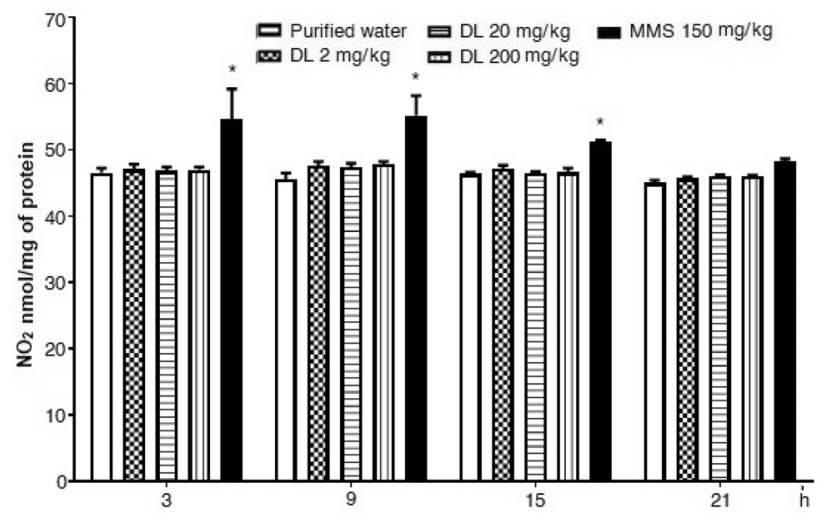

Figure 8. Effect of duloxetine (DL) and methyl metanesulfonate (MMS) on the content of nitrites $\left(\mathrm{NO}_{2}\right)$ in mouse brain cells. Each bar corresponds to the mean \pm SEM obtained in 5 independent determinations made in triplicate. ${ }^{\star}$ Statistically significant difference with respect to control value. ANOVA and post hoc StudentNewman-Keuls tests $(p \leq 0.05)$.

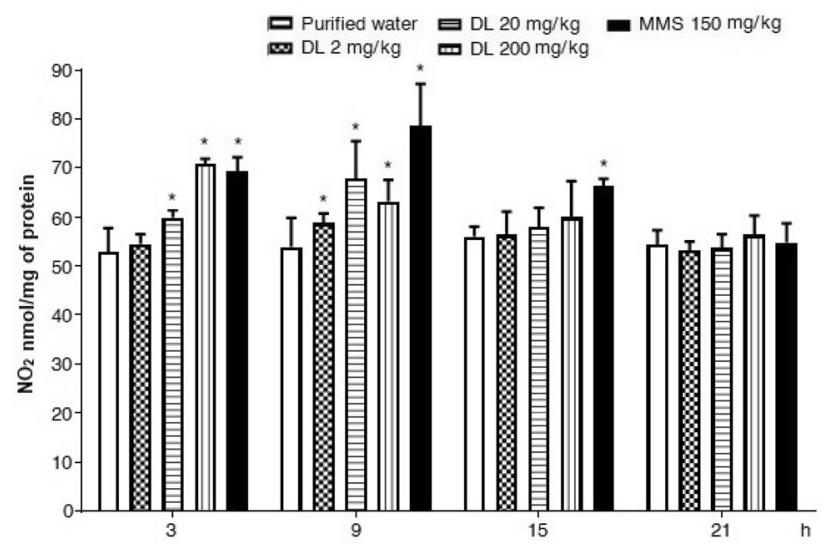

Figure 9. Effect of duloxetine (DL) and methyl metanosulfonate (MMS) on the content of nitrites $\left(\mathrm{NO}_{2}\right)$ in mouse hepatic cells. Each bar corresponds to the mean \pm SEM obtained in 5 independent determinations made in triplicate. ${ }^{\star}$ Statistically significant difference with respect to control value. ANOVA and post hoc StudentNewman-Keuls test $(p \leq 0.05)$. 
with the two low doses in the case of liver cells. Our results show a time-curve with pre-damage, the maximum damage, and its decline to normality, which reflects the DNA damage potential and the repair process.

Concerning DNA oxidation, it is known that this may be caused by several oxidants that can produce base and sugar damage, strand breaks, clustered sites, and other lesions, and that these alterations are mainly repaired with the participation of DNA glycosylases ${ }^{25}$. In this context, the FPG protein is a DNA base excision repair enzyme that catalyzes the removal of oxidized purines, such as the mutagenic 7-hydro-8-oxoguanine lesion, by the activity of $\mathrm{N}$-glycosylase ${ }^{26}$. At the location of oxidized DNA bases, additional DNA strand breaks occur which leads to DNA migration. This knowledge has been applied to the comet assay to detect the oxidative influence of numerous agents and, in the present study, to the oxidative potential of duloxetine. Interestingly, by using this approach we demonstrated the DNA oxidative effect of the drug, although with the two high doses tested, as shown by the significant elevation of DNA breaks when the FPG enzyme was incorporated to the comet assay, in comparison with the comet assay without such enzyme, an effect that was observed in both organs. In concordance with such findings, we also observed an elevated induction of lipoperoxidation by duloxetine, as well as oxidized proteins, and nitric oxide in liver cells, as well as of lipid peroxidation and oxidized proteins in brain cells, with a clear effect at $9 \mathrm{~h}$ post-administration in both organs; a time-point that coincides with that required to induce the highest DNA damage, as shown with the comet assay.

Oxidative stress is the imbalance in the redox characteristics of some cellular environments, which can be the result of exposure to damaging agents or to the limited capabilities of endogenous antioxidant systems ${ }^{27,28}$. In our present study, we found oxidation in all evaluated molecules, suggesting a higher damaging potential of duloxetine than previously reported.

Oxidation of DNA components is the major source of induced DNA damages leading to several types of modifications including nucleotide oxidation, strand breakage, loss of bases, and adduct formation. The HO. radical can react with purine and pyrimidine bases and deoxyribose backbone generating products such as the 8 oxodG ${ }^{29}$. Damaged DNA replication may lead to gene mutation, which in turn may give rise to altered proteins. Besides, mutations that affect an oncogene, a tumor suppressor gene, or a gene that controls the cell cycle can generate a clonal cell population with a distinct advantage in proliferation ${ }^{30}$.

Lipid peroxidation is a process under which oxidants attack lipids containing carbon-carbon double bonds, especially polyunsaturated fatty acids. One of the most prevalent ROS that can affect the lipids is the hydroxyl radical, a small, highly mobile, water soluble and highly reactive species of activated oxygen, this radical, can cause oxidative damage to cells because non-specifically attack biomolecules close to its site of generation ${ }^{31}$. In general, when oxidant compounds target lipids, they can initiate the lipid peroxidation process, a chain reaction that produces multiple breakdown molecules, such as MDA and 4-hydroxy-nonenal. Among various substrates, proteins and DNA are susceptible to modifications caused by these aldehydes. Besides, the adducts play a critical role in multiple cellular processes and can participate in secondary deleterious reactions, by proting intramolecular or intermolecular protein/DNA crosslinking that may induce profound alterations in the biochemical properties of biomolecules ${ }^{31,32}$.

As proteins are highly abundant and react rapidly with many oxidants, they are highly susceptible and major targets to oxidative damage. Thus, oxidant alteration in most biological systems is likely to be skewed toward proteins, although other factors play an important role, including localization of the generating system relative to the target, membrane barriers, binding of the oxidant system to a target, and the occurrence of secondary reactions ${ }^{33}$. A number of radicals, two-electron oxidants, and metal-oxo complexes may modify proteins also reactions of secondary products, such as aldehydes, quinones and dehydroalanine are a further source of modifications ${ }^{34,35}$. Carbonyl groups can be generated by different mechanisms and, therefore, their concentration is commonly higher than other biomarkers ${ }^{36}$. Due to these characteristics, the measure of carbonyl levels is the most used marker of oxidative protein damage. Protein carbonyls can be formed by the oxidative cleavage of protein backbone, oxidative deamination of lysine and glutamic acid, or by binding of aldehydic lipid oxidation products to lysine, cysteine, and histidine residues. Also, the reaction between lysine and arginine residues with carbohydrates result in advanced glycation end products ${ }^{37}$.

The free radical nitric oxide (NO*) exerts biological effects through direct and reversible interactions with specific targets, such as soluble guanylate cyclase, or through the generation of secondary species, many of which can oxidize, nitrosate or nitrate biomolecules ${ }^{38,39}$. The species formed downstream by NO• include nitrogen dioxide, dinitrogen trioxide, nitroxyl, and peroxynitrite, as well as hydroxyl and carbonate anion radicals ${ }^{37}$. Many of these products are reactive and yield further products. Peroxynitrite for example, generate nitrites, nitrates, hydroxyl radicals, and carbonate anion radicals ${ }^{37,38}$. The preferential targets of oxide nitric derived oxidants in biological systems are located in close proximity and determined by a combination of factors, including target concentration, compartmentalization, and membrane permeability. Moreover, some of these derived oxidants are good one-electron oxidants that start oxygen-dependent chain reactions in both aqueous and lipid compartments, which may amplify the effects ${ }^{38}$.

The above described characteristics of the examined biomarkers demonstrate their relevance at the molecular and cellular level, moreover because they can interact among them to increase their damaging potential, and because all reports point to the fact that their alterations are reflected in human disease, such as aging, inflammation, cancer, and particular damage in the nervous, cardiovascular, immune, metabolic, endocrine, renal, and respiratory systems $s^{30,32,37,40,41}$. Therefore, our findings clearly suggest the importance to confirm or modulate the described effect of duloxetine. Is in this field, that experimental sub-chronic or chronic research can be carried out, as well as the appropriate monitoring of patients under long-term treatment.

Our observed molecular oxidation could be attributed to the participation of duloxetine epoxide during the formation of dihydrodiol-duloxetine and 5 hydroxy or 6 hydroxy duloxetine during duloxetine metabolism ${ }^{42}$, or because of the bioactivation of the naphthyl ring to generate quinones or epoxides, or related to the thiophene ring that may be bioactivated to generate epoxides, ring-opening or S-oxidation products ${ }^{43}$. In this respect, it is 
known that epoxides may give rise to point mutations, deletions, chromosomal aberrations, gene conversion, crossing over, cancer, and virus induction. Moreover, the release of free radicals or ROS by epoxide metabolites have also been suggested to participate in the hepatotoxic damage induced by duloxetine ${ }^{44}$.

Our oxidative findings are congruent with the report by Czarny et al. $^{45}$ on depressed patients under treatment, because these authors determined a higher level of DNA breaks, alkali-labile sites, and oxidative DNA damage in the patients in comparison with normal individuals, and concluded that the observed lesions may be accumulated by impairment of repair systems; moreover, the authors also refer to previous reports showing increased levels of 8-oxo-G in urine, serum, or peripheral blood of patients. However, the oxidation of lipids, proteins, and nitric oxide by duloxetine had not been reported before in our present experimental conditions, and, therefore, the findings suggest the need to extend studies on the matter to ratify the observations or to modulate them. Besides, the oxidative effect by the antidepressant seems an interesting investigative and theoretical theme in light of the published controversial data. Various authors have reported neuroprotection exerted by duloxetine against oxidation, for example, by decreasing the level of dismutase and glutathione peroxidase in rats, by the lowering of intracellular rat neuron ROS production, antagonizing rotenone-induced overproduction of ROS and cell death in human neuroblastoma cells, or by increasing antioxidative capacity in patients under antidepressant treatment ${ }^{45-49}$.

In conclusion, we demonstrated DNA damage induced by duloxetine by means of a time-kinetic study, particularly in liver tissue where the increase was found even with the low tested dose, which corresponds to the high therapeutic range recommended for depressed patients. In our assay, we were able to follow the behavior curve when a single administration of the drug was administered, and found the highest DNA damage at $9 \mathrm{~h}$ post-administration, followed by a repair up to $21 \mathrm{~h}$. The basis of our duloxetine damaging findings are probably connected with the oxidation determined in DNA, lipids, proteins, and nitric oxide. Therefore, our results strongly suggest the pertinence to extend the research on the potential toxic effect of duloxetine, as well as to be cautious with the long-term drug prescription.

Received: 23 October 2020; Accepted: 9 March 2021

Published online: 25 March 2021

\section{References}

1. Dean, J. \& Keshavan, M. The neurobiology of depression: An integrated view. Asian J. Psychiatry. 27, 101-111 (2017).

2. Furukawa, T. A., Cipriani, A., Barbui, C. \& Geddes, J. A. Long-term treatment of depression with antidepressants: A systematic narrative review. Can. J. Psychiatry. 52, 545-552 (2007).

3. Shinohara, K. et al. Comparative efficacy and acceptability of antidepressants in the long-term treatment of major depression: Protocol for a systematic review and network meta-analysis. BMJ Open 9, 1-9 (2019).

4. Anttila, S. \& Leininen, E. Duloxetine Eli Lilly. Curr. Opin. Investig. Drugs 3, 1217-1221 (2002).

5. Wernicke, J. F. et al. Safety and adverse event profile of duloxetine. Expert. Opin. Drug Saf. 4, 987-993 (2005).

6. Di Poi, C. et al. Toxicity of five antidepressant drugs on embryo-larval development and metamorphosis success in the Pacific oyster, Crassostrea gigas. Environ. Sci. Pollut Res. Int. 21, 13302-13314 (2014).

7. Lassen, D., Ennis, Z. N. \& Damkier, P. First-trimestrer pregnancy exposure to venlafaxine or duloxetine and risk of major congenital malformations: A systematic review. Basic Clin. Pharmacol. Toxicol. 118, 32-36 (2016).

8. Brambilla, G., Mattioli, F. \& Martelli, A. Genotoxic and carcinogenic effects of antipsychotics and antidepressants. Toxicology 261, $77-88$ (2009).

9. Madrigal-Bujaidar, E., Álvarez-González, I., Madrigal-Santillán, E. O. \& Morales-González, J. A. Evaluation of duloxetine as micronuclei inducer in an acute an a subchronic assay. Biol. Pharm. Bull. 38, 1245-1249 (2015).

10. Madrigal-Bujaidar, E. et al. Genotoxic evaluation of duloxetine II. The effect on the number of sister chromatid exchanges, the mitotic index, and the proliferation kinetics in mouse bone marrow. Biol. Pharm. Bull. 40, 1796-1800 (2017).

11. Pereira, P. et al. Neurobehavioral and genotoxic parameters of duloxetine in mice using the inhibitory avoidance task and comet assay as experimental models. Pharmacol. Res. 59, 57-61 (2009).

12. National Center for Biotechnology Information (2021). PubChem Compound summary for CID 60834, Duloxetine hydrochloride. https://pubchem.ncbi.nlm.nih.gov/compound/duloxetinehydrochloride.

13. ARRIVE guidelines. https://arriveguidelines.org.

14. OECD 489. Guideline for the testing of chemicals. In vivo mammalian alkaline comet assay. https://www.oecd-ilibrary.org/envir onment/test-no-489-in-vivo-mammalian-alkaline-comet-assay_9789264264885-en.

15. Collins, A.R. \& Dušinská, M. Oxidation of cellular DNA measured with the comet assay. In Oxidative Stress Biomarkers and Antioxidant Protocols. Methods in Molecular Biology 147-159 (ed. Armstrong, D.) 1st. Humana Press. University of Florida, Gainesville (2002).

16. Bradford, M. B. A rapid and sensitive method for the quantitation of micrograms quantities of protein utilizing the principle of protein-dye binding. Anal. Biochem. 72, 248-254 (1976).

17. Buege, J. \& Aust, S. Microsomal lipid peroxidation. Methods Enzymol. 52, 302-310 (1978).

18. Levine, R., Garland, D. \& Oliver, C. Determination of carbonyl content in oxidatively modified proteins. Methods Enzymol. 186, 464-478 (1990).

19. Miranda, K., Espey, W. \& Wink, D. A rapid, simple spectrophotometric method for simultaneous detection of nitrate and nitrite. Nitric Oxide 5, 62-71 (2001).

20. D'Sousa, P. \& Jago, C. Spotlight on depression: A pharma matters report. Drugs Today 50, 251-267 (2014).

21. Jackson, M., Marks, L., May, G. H. W. \& Wilson, J. B. The genetic basis of disease. Essays Biochem. 62, 643-723 (2018).

22. Karbaschi, M. et al. Evaluation of the major steps in the conventional protocol for the alkaline comet assay. Int. J. Mol. Sci. 20, 6072-6085 (2019).

23. Skinner, M. H. et al. Effect of age on the pharmacokinetics of duloxetine in women. Br. J. Clin. Pharmacol. 57, 54-61 (2004).

24. Zhao, R. K., Cheng, G., Tang, J., Song, J. \& Peng, W. X. Pharmacokinetics of duloxetine hydrochloride enteric-coated tablets in healthy Chinese volunteers: A randomized, open-label, single-and multiple-dose study. Clin. Ther. 31, 1022-1036 (2009).

25. Dizdaroglu, M., Coskun, E. \& Jaruga, P. Repair of oxidatively induced DNA damage by DNA glycosylases: mechanisms of action, substrate specificities and excision kinetics. Mutat. Res. 77, 99-127 (2017).

26. Koval, V. V., Kusnetzov, N. A., Ischenko, A. A., Saparbaev, M. K. \& Fedorova, O. Real-time studies of conformational dynamics of the repair enzyme E. coli formamidopyrimidine-DNA glycosylase and its DNA complexes during catalytic cycle. Mutat. Res. 685, 3-10 (2010). 
27. Bickers, D. R. \& Athar, M. Oxidative stress in the pathogenesis of skin disease. J. Invest. Dermatol. 126, 2565-2575 (2006).

28. Marrocco, I., Altieri, F. \& Peluso, I. Measurement and clinical significance of biomarkers of oxidative stress in humans. Oxid. Med. Cell Longev. 2017, 6501046 (2017).

29. Roberts, R. A. et al. Toxicological and pathophysiological roles of reactive oxygen and nytrogen species. Toxicology 276, 85-94 (2010).

30. Basu, A. K. DNA damage, mutagenesis and cancer. Int. J. Mol. Sci. 19, 970 (2018).

31. Ayala, A., Muñoz, M. \& Argüelles, S. Lipid peroxidation: production, metabolism, and signaling mechanisms of malondialdehyde and 4-hydroxy-2-nonenal. Oxid. Med. Cell Longev. 2014, 1-57 (2014).

32. Tsikas, D. Assessment of lipid peroxidation by measuring malondialdehyde (MDA) and relatives in biological samples: analytical and biological challenges. Anal. Biochem. 524, 13-30 (2017).

33. Davies, M. J. Protein oxidation and peroxidation. Biochem. J. 473, 805-825 (2016).

34. Grimsrud, P. A., Xie, H., Griffin, T. J. \& Bernlohr, D. A. Oxidative stress and covalent modification of protein with bioactive aldehydes. J. Biol. Chem. 283, 21837-21841 (2008).

35. Shu, N., Lorentzen, N. G. \& Davies, M. J. Reaction of quinones with proteins: Kinetic of adduct formation, effects of enzymatic activity and protein structure, and potential reversibility of modifications. Free Radic. Biol. Med. 137, 169-180 (2019).

36. Dean, R. T., Fu, S., Stocker, R. \& Davies, M. J. Biochemistry and pathology of radical-mediated protein oxidation. Biochem. J. 324, $1-18$ (1997).

37. Hawkins, C. L. \& Davies, M. J. Detection, identification, and quantification of oxidative protein modifications. J. Biol. Chem. 294, 19683-19708 (2019).

38. Ferrer-Sueta, G. et al. Biochemistry of peroxynitrite and protein tirosine nitration. Chem. Rev. 118, 1338-1408 (2018).

39. Radi, R. Nitric oxide, oxidants, and protein tyrosine nitration. Proc. Nat. Acad. Sci. USA 101, 4003-4008 (2004).

40. Frijhoff, J. et al. Clinical relevance of biomarkers of oxidative stress. Antioxid Redox Signal. 23, 1144-1170 (2015).

41. Möller, M. N. et al. Detection and quantification of nitric oxide-derived oxidants in biological systems. J. Biol. Chem. 294, 1477614802 (2019).

42. Lantz, R. J. et al. Metabolism, excretion, and pharmacokinetics of duloxetine in healthy human subjects. Drug Metab. Dispos. 31, $1142-1150$ (2003)

43. Chan, C. Y., New, L. S., Ho, H. K. \& Yong, C. E. C. Reversible time-dependent inhibition of cytochrome P450 enzymes by duloxetine and inertness of its thiophene ring towards bioactivation. Toxicol. Lett. 206, 314-324 (2011).

44. Mishra, A. et al. Oxidative stress-based hepatotoxicity in Wistar rat. Int. J. Pharm. Pharm. Sci. 8, 28-32 (2016).

45. Czarny, P. et al. Elevated level of DNA damage and impaired repair of oxidative DNA damage in patients with recurrent depressive disorder. Med. Sci. Monit. 21, 412-418 (2015)

46. Engel, D. F. et al. Duloxetine protects human neuroblastoma cells from oxidative stress-induced cell death through Akt/Nrf-2/ HO-1-pathway. Neurochem. Res. 43, 387-396 (2018).

47. Akpinar, A., Ugus, A. C. \& Naziroglu, M. Agomelatine and duloxetine synergistically modulates apoptotic pathway by inhibiting oxidative stress triggered intracellular calcium entry in neuronal PC12 cells: Role of TRPM2 and voltage-gated calcium channels. J. Membr. Biol. 247, 451-459 (2014).

48. Rahimi, B. M., Motaghinejad, M., Motevalian, M. \& Gholami, M. Duloxetine by modulating the Akt/GSK3 signaling pathways has neuroprotective effects against methamphetamine-induced neurodegeneration and cognition impairment. Iran J. Med. Sci. 44, 146-154 (2019).

49. Demirdas, A., Naziroglu, M. \& Ovey, I. S. Duloxetine reduces oxidative stress, apoptosis, and $\mathrm{Ca}^{2+}$ entry through modulation of TRPM2 and TRPV1 channels in the hippocampus and dorsal root ganglion of rats. Mol. Neurobiol. 54, 4683-4695 (2017).

\title{
Author contributions
}

E.M.B. e I.A.G. designed the experiment and wrote the manuscript. S.C.C., P.G.G., and M.J.R.B. made the two types of comet assay. J.A.M.G., E.O.M., and R.P.P. made the oxidative assays.

\section{Funding}

The present work received no funding.

\section{Competing interests}

The authors declare no competing interests.

\section{Additional information}

Correspondence and requests for materials should be addressed to E.M.-B.

Reprints and permissions information is available at www.nature.com/reprints.

Publisher's note Springer Nature remains neutral with regard to jurisdictional claims in published maps and institutional affiliations.

\begin{abstract}
Open Access This article is licensed under a Creative Commons Attribution 4.0 International License, which permits use, sharing, adaptation, distribution and reproduction in any medium or format, as long as you give appropriate credit to the original author(s) and the source, provide a link to the Creative Commons licence, and indicate if changes were made. The images or other third party material in this article are included in the article's Creative Commons licence, unless indicated otherwise in a credit line to the material. If material is not included in the article's Creative Commons licence and your intended use is not permitted by statutory regulation or exceeds the permitted use, you will need to obtain permission directly from the copyright holder. To view a copy of this licence, visit http://creativecommons.org/licenses/by/4.0/.
\end{abstract}

(C) The Author(s) 2021 